\title{
Toward a Post-Atonement America: The Supreme Court's Atonement for Slavery and Jim Crow
}

\author{
Roy L. Brooks ${ }^{*}$
}

\section{INTRODUCTION}

Little if any attention in the national discourse on reparations has been given to the question of whether the United States Supreme Court has an institutional moral duty to atone for its participation in the atrocities of slavery and Jim Crow. By "atonement" I mean two things: a statement of apology and an act of redemption that concretizes the apology, making it believable. ${ }^{1}$ Properly speaking, this act of redemption is called a "reparation." Hence, atonement is defined as an apology plus an accompanying reparation, and a reparation is defined as the tangible act that transforms the rhetoric of apology into a material, meaningful reality. There is, then, a strong correlation between an apology and a reparation.

The question of judicial atonement can be analyzed through a series of cognate questions. First, what approach should we use in analyzing the question of judicial atonement? ${ }^{3}$ This is the threshold question. Second, can the Court's moral culpability for slavery and Jim Crow be established? ${ }^{4}$ Third, is the Court's post-Brown v. Board of Education, post-Jim Crow judicial philosophy sufficient to atone for slavery and Jim Crow? ${ }^{5}$ Assuming the answer to that question is negative, then a final question arises: is it possible to construct a new judicial philosophy that atones for slavery and Jim Crow ${ }^{6}$ I shall address these questions seriatim.

\footnotetext{
Warren Distinguished Professor of Law, University of San Diego.

1. See Roy L. Brooks, Atonement and Forgiveness: A New Model for Black REPARATIONS ix (2004) [hereinafter BROOKS, ATONEMENT AND FORGIVENESS] (noting that "[a]tonement would give our government moral credibility and direction through the fog that often engulfs contemporary racial matters").

2. Id. at 155 .

3. See infra Part II.

4. See infra Part III.A-B.

5. See infra Part IV.

6. See infra Part V.
} 


\section{How to APPROACH THE QUESTION OF JUDICIAL ATONEMENT}

Tommie Shelby, a young black philosopher at Harvard, argues in his book, We Who Are Dark: The Philosophical Foundations of Black Solidarity, that civil rights theory, insofar as it relates to blacks, "must not be utopian - [that is] applicable only in an ... ideal but unrealizable world - but must [instead] be politically viable given the sociohistorical circumstances of contemporary black Americans."7 I profoundly disagree. As I argue extensively in Racial Justice in the Age of Obama, our earliest civil rights theories were utopian when first articulated. The theory of abolition during the antebellum period and the theory of equal rights during Jim Crow seemed sappy and farcical to many on both sides of the color line. Yet, black leaders like Frederick Douglass and Martin Luther King, Jr., were assiduous proponents of abolition and equal rights, respectively. ${ }^{9}$

These civil rights theories - abolition and equal rights - were simply ahead of their times. The nation had to catch up, and when it did, it changed in the most practical of ways. But like all successful revolutionary ideas, abolition and equal rights passed through certain stages before they were regarded as truths. Indeed, Arthur Schopenhauer, the great German philosopher (1788-1860), insists that "[e]very truth passes through three stages before it is recognized. In the first stage it is ridiculed, in the second it is opposed, in the third it is regarded as self-evident." 10

This suggests that theorists who endeavor to address the issue of reparations should think big. They should demonstrate the courage to dream like Frederick Douglass and Martin Luther King, Jr. This does not mean, of course, that the sky is the limit and we should all be space cadets. Reparations should be limited by what can be called "practical idealism." This simply means that the reparatory duty should fall within the reach of morally motivated individuals and institutions. When the perpetrator of an atrocity is asked to redress its own wrongdoing, the requested reparation should be something that a person of probity and intelligence, acting individually or institutionally, is physically capable

7. Tommie Shelby, We Who Are Dark: The Philosophical foundations of Black SOLIDARITY 250 (2005).

8. Roy L. Brooks, Racial Justice IN the Age of Obama (forthcoming 2009).

9. See, e.g., Frederick Douglass, Life AND Times of Frederick Douglass: His Early LifE AS A SLAVE, His ESCAPE FROM BONDAGE, AND His COMPLETE HISTORY (First Collier Books 1962) (1892); Martin Luther King, Jr., Letter from Birmingham City Jail, in THE AMERICAN CIVIL RigHTS MOVEMENT: READINGS \& INTERPRETATIONS 320-31 (Raymond D'Angelo ed., 2001).

10. BROOKS, ATONEMENT AND FORGIVENESS, supra note 1, at ix. 
of doing. Hence, as theorists, our job is to seek coherent, logical, and morally desirable prescriptions before the horse trading and ox-going (i.e., politics) begin.

Practical idealism, then, comes into play at the reparatory stage of atonement. The "idealism" in practical idealism helps to shape morally responsive reparations. The "practical" in practical idealism narrowly tailors the reparation to the nature and scope of the antecedent atrocity. We begin the reparatory process with a firm understanding of the perpetrator's moral transgression.

\section{THE SUPREME COURT's MORAL CULPABILITY}

During slavery and Jim Crow, the Court consistently validated a racist ideology that had both the intent and effect of subordinating blacks in case after case. The consequences for blacks were dire and lasting. Blacks were denied basic liberties, including, in many instances, the right to life itself. ${ }^{11}$ Slavery created, and Jim Crow perpetuated, no dearth of capital deficiencies in black America-financial capital deficiencies (i.e., property and income), human capital deficiencies (i.e., formal education and skills), and social capital deficiencies (i.e., the lack of social rank and respect and the inability to get things done).

Several landmark cases illustrate how the Court oppressed black Americans: Dred Scott v. Sandford ${ }^{12}$ arguably the most infamous Court decision in history, the Civil Rights Cases, ${ }^{13}$ a post-bellum consolidated case that dug a large civil rights hole for the recently freed slaves, and Plessy v. Ferguson, ${ }^{14}$ a case that shoved blacks into this racial abyss. Acting through its interpretive function, the Court in these cases constitutionalized the oppression of blacks by the government and private parties.

11. See generally John Hope Franklin \& Alfred A. Moss, Jr., From Slavery to FrEedom: A History OF NEGRO AMERICANS 14 (6th ed. 1988) (explaining that the Slave Codes deemed slaves not to be persons, but property, and that laws were designed to protect the owners' property rights in slaves); A. LEON HigGinBOTHAM, JR., IN THE MATTER OF COLOR: RACE AND THE American Legal Process: The Colonial Period 6 (1978) (noting that "the Constitution's references to justice, welfare, and liberty were mocked by the treatment" of blacks by the legal system throughout the Nation's early history).

12. 60 U.S. (19 How.) 393 (1856), superseded by U.S. CONST. amends. XIII, XIV.

13. 109 U.S. 3 (1883).

14. 163 U.S. 537 (1896), overruled by Brown v. Bd. of Educ. of Topeka, 347 U.S. 483 (1954). 


\section{A. Dred Scott v. Sandford}

In Dred Scott, the Court had an opportunity to delegitimize, or at least limit, the legitimacy of human bondage. ${ }^{15}$ Rather than pursuing either course of action, the Court chose to give its imprimatur to America's greatest atrocity. The facts of the case are not complicated. Dred Scott was a slave living in a free state, having been brought there by his master. ${ }^{16}$ He sued his master in federal court to secure his freedom. ${ }^{17}$ The Court ruled against Dred Scott, holding that blacks, whether enslaved or free, were not citizens of the United States and, therefore, had no legal status to sue in federal court under diversity jurisdiction. ${ }^{18}$ The Court's holding was based on more than an originalist interpretation of the Constitution. Moving beyond the text of the Constitution, Chief Justice Taney also relied upon public policy considerations. He noted that if Dred Scott succeeded in this litigation, his owner, who had brought Dred Scott and his wife into the free state of Illinois for an extended period of time, would be deprived of his property. ${ }^{19}$ The Court, in other words, determined slaves were nothing more than property. ${ }^{20}$ To drive home this point, the Court observed that blacks:

$[\mathrm{H}] \mathrm{ad}$ for more than a century before been regarded as beings of an inferior order, and altogether unfit to associate with the white race, either in social or political relations; and so far inferior, that they had no rights which the white man was bound to respect; and [so] ... the negro might justly and lawfully be reduced to slavery for his benefit. ${ }^{21}$

Clearly, the Court's judicial philosophy — originalism — was a fig leaf for the Court's racism and unconditioned support of slavery. As the late Judge A. Leon Higginbotham has noted, "[t]he opinion of the Court,

15. 60 U.S. at 393.

16. Id. at $458-59$.

17. Id. at 400 .

18. See id. at 404-05, 407. Article III, Section 2 of the Constitution extends the judicial power of the United States to citizens of different states. U.S. CONST. art. III, § 2, cl. 1.

19. 60 U.S. at $450-51$.

20. Id.; see supra note 11 and accompanying text.

21. 60 U.S. at 407; see also A. LeON Higginbotham, JR., Shades of Freedom: Racial POLITICS AND PRESUMPTIONS OF THE AMERICAN LEGAL PROCESS 65 (1996) [hereinafter HigGinbotham, JR., Shades OF FreEdom] But cf. BRoOKS, Atonement AND ForgivenESS, supra note 1, at 133-34 (discussing the inaccuracies in Chief Justice Taney's originalist argument in Dred Scott); Alexander Tsesis, Undermining Inalienable Rights: From Dred Scott to the Rehnquist Court, 39 ARIZ. ST. L.J. 1179, 1200-07 (2007) (also discussing the Chief Justice's inaccuracies in Dred Scott). 
while clothed in the usual garments of legal theory, was in effect nothing more than a southern manifesto on the institution of slavery."22 Although the Fourteenth Amendment would give blacks citizenship, thereby reversing the specific holding in Dred Scott, ${ }^{23}$ the Court continued its pattern of juridical subordination long after that Amendment's ratification.

\section{B. The Civil Rights Cases $^{24}$ and Plessy v. Ferguson ${ }^{25}$}

During the post-bellum period, blacks were still regarded by most whites as beast-like, unteachable, uncouth, odious, and inferior to whites in every essential respect. Blacks were subjected to laws and customs that perpetuated the capital deficiencies wrought by slavery. Racially repressive Slave Codes, enacted in the South during slavery to control slaves and free blacks alike, were replaced after Reconstruction with a rigid regime of segregation laws in the South. ${ }^{26}$ The constitutional legitimacy of these laws, known as "Jim Crow" laws, was presented to the Court at the end of the nineteenth century in Plessy v. Ferguson. ${ }^{27}$ However, several cases, consolidated in a single case, set the stage for Plessy and the subsequent constitutionalization of Jim Crow.

Known as the Civil Rights Cases, five of these cases were consolidated before the Court in 1883. ${ }^{28}$ The Court held that Congress lacked the authority under the enforcement provision of the Fourteenth Amendment to ban racial discrimination by private individuals and organizations. ${ }^{29}$ This holding made it difficult for Congress to protect black Americans from racial oppression. For this reason, Justice Harlan wrote a dissenting opinion challenging the Court's narrow interpretation of the Fourteenth Amendment. He argued that Congress, in enacting the civil rights legislation, was attempting to overcome an intolerable situation: southern states refusing to grant black citizens the same legal rights granted to white citizens. ${ }^{30}$

\footnotetext{
22. Higginbotham, JR., SHAdes OF Freedom, supra note 21, at 61.

23. U.S. CONST. amend. XIV, $\S 1$ ("All persons born or naturalized in the United States ... are citizens of the United States ....”).

24. 109 U.S. 3 (1883).

25. 163 U.S. 537 (1896), overruled by Brown v. Bd. of Educ. of Topeka, 347 U.S. 483 (1954).

26. See BRooks, Atonement AND Forgiveness, supra note 1, at 22-23, 64 .

27. 163 U.S. 537.

28. 109 U.S. 3.

29. Id. at $10-11$.

30. Id. at 26-27 (Harlan, J., dissenting).
} 
If the Civil Rights Cases dug a large hole for black Americans, Plessy pushed blacks into that hole. In Plessy, the Court upheld the constitutionality of a Louisiana statute that segregated riders on railway cars. The Court's holding constitutionalized the "separate-but-equal doctrine" under the Equal Protection Clause of the Fourteenth Amendment. The separate-but-equal doctrine states that the races are to be held separate, but equal, meaning, of course, unequal. ${ }^{31}$ This doctrine established the constitutional foundation for Jim Crow laws, which permitted states to create separate schools, separate drinking foundations, separate hospitals, and so on. ${ }^{32}$

Plessy, in short, gave the nation constitutional cover to subordinate blacks, plain and simple. The racial segregation and discrimination that took place under the separate-but-equal doctrine made a mockery of the equality part of the doctrine. As John Hope Franklin and Alfred A. Moss, Jr., have noted:

By 1898 the pattern for the constitutional disfranchisement of blacks had been completely drawn. In subsequent years other states followed the lead of Mississippi, South Carolina, and Louisiana. By 1910 blacks had been effectively disfranchised by constitutional provisions in North Carolina, Alabama, Virginia, Georgia, and Oklahoma.

... [T]he Negro was banned from white hotels, barber shops, restaurants, and theatres.... [M] ost Southern states had laws requiring separate schools. ${ }^{33}$

Jim Crow was not, however, limited to the South. The Civil Rights Cases and Plessy were decided under the Constitution and, therefore, established national law. The North, although not as segregated by law (de jure segregation) as the South, was certainly segregated by custom (de facto segregation). ${ }^{34}$ As Harry Ashmore has pointed out, "[t]he

31. See Roy L. Brooks et al., Civil Rights Litigation: Cases and Perspectives 9-11 (3d ed. 2005) [hereinafter BroOKS ET AL., CiVIL Rights Litigation].

32. Id. at 9 .

33. John Hope Franklin, From Slavery to Freedom: A History of Negro Americans, 265-66 (5th ed. 1988); see also id. at 235-38 (providing an overview of constitutional disfranchisement of blacks).

34. For an explanation of de jure and de facto segregation, along with an overview of Jim Crow laws and customs, see generally C. VANN WOODWARD, THE STRANGE CAREER OF JiM CROW (2d ed. 1966). 
concept of white supremacy had been exalted in the South in defense of slavery, but it was by no means confined to the region." ${ }^{35}$

As he had in the Civil Rights Cases,${ }^{36}$ Justice Harlan dissented in Plessy, challenging, once again, the Court's narrow interpretation of the Fourteenth Amendment. In his famous dissent, Justice Harlan argued: "[o]ur constitution is color-blind, and neither knows nor tolerates classes among citizens.... The law regards man as man, and takes no account of his surroundings or of his color ...., 37 Justice Harlan's opinion gave birth to the "color-blind principle," which would eventually become the principal interpretative standard for the Fourteenth Amendment's Equal Protection Clause after Brown v. Board of Education. ${ }^{38}$

It is important to note, however, that Justice Harlan himself did not envision the color-blind principle doing much, if anything, to change the social condition of blacks relative to whites. As he said:

The white race deems itself to be the dominant race in this country. And so it is, in prestige, in achievements, in education, in wealth and in power. So, I doubt not, it will continue to be for all time, if it remains true to its great heritage, and holds fast to the principles of constitutional liberty.

Thus, Justice Harlan saw the color-blind principle as changing only the legal status of blacks rather than their socioeconomic status. In his view, a color-blind Constitution would not upset the prevailing racial orderwhites would always be on top. This is more than the soft bigotry of low expectations from the Court's most liberal justice - it is unabashed white supremacy.

The Court's decisions in cases like Dred Scott, the Civil Rights Cases, and Plessy constitute juridical oppression, or juridical subordination. Each case provided legal cover for the atrocities of slavery and Jim Crow to unfold across America. For that reason, the Court is morally culpable for slavery and Jim Crow. The Court,

35. HARRY S. ASHMORE, HEARTS AND MindS: THE ANATOMY OF RACISM FROM ROOSEVELT TO REAGAn 138 (1982). See generally John Hope Franklin, History of Racial Segregation in the United States, 304 ANNALS AM. ACAD. POL. \& SOC. SCI. 1, 1-2 (1956) (providing an overview of racial segregation throughout the entire nation).

36. See supra text accompanying notes $28-30$.

37. Plessy v. Ferguson, 163 U.S. 537, 559 (1896) (Harlan, J., dissenting), overruled by Brown v. Bd. of Educ. of Topeka, 347 U.S. 483 (1954); see Fullilove v. Klutznick, 448 U.S. 448, 522-23 (1980) (Stewart, J., dissenting), abrogated by Adarand Constructors, Inc. v. Pena, 515 U.S. 200 (1995).

38. See Brooks et AL., Civil Rights Litigation, supra note 31, at 11-12.

39. Plessy, 163 U.S. at 559 (Harlan, J., dissenting). 
therefore, has incurred a moral obligation to atone for its unique participation in these past atrocities.

\section{POST-BROWN JUDICIAL PHILOSOPHY}

Brown v. Board of Education ${ }^{40}$ unconstitutionalized Jim Crow in public education and hence set the stage for its eventual demise. ${ }^{41}$ Given that important fact, it is reasonable to ask: does the Court's post-Brown judicial philosophy constitute atonement for slavery and Jim Crow? My answer is no, because the Court today employs several racially subordinating judicial philosophies. Several structural elements that subtly, yet effectively, subordinate blacks are embedded in the Court's judicial techniques.

When the Court decides cases, it typically proceeds at three alternative levels, what I will refer to as Levels 1,2 , and $3 .^{42}$ Level 1 is more commonly known as judicial positivism. It can be defined as the quest for justice disciplined by extant rules. ${ }^{43}$ Judicial fidelity to past rules, what is sometimes called a "normativity of consistency," is the hallmark of Level $1 .^{44}$

A jurisprudence of judicial consistency can be manifested as legal formalism or originalism (which is a feature of textualism). ${ }^{45}$ Neither expression of judicial consistency is friendly toward blacks. For example, legal formalism consists of syllogistic reasoning loaded with nonprogressive, minimalist legal doctrine; mainly, liberty of contract, substantive due process, and vested property rights. ${ }^{46}$ These doctrines protect privilege and property, of which, today, as in the past, blacks

40. 347 U.S. 483.

41. Brown v. Board of Education changed the legal status of blacks from mere supplicants begging to be treated as both full-fledged citizens of the United States and members of the human race, to persons entitled to equal treatment under the law. This in turn made the burgeoning civil rights movement a less difficult struggle than it otherwise would have been. For example, the 1964 Civil Rights Act would not have been possible without Brown, for it is doubtful a racially skittish Congress would have passed a civil rights statute in contravention of the constitutional principle of separate-but-equal. See Robert L. Carter, The Warren Court and Desegregation, 67 Mich. L. ReV. 237 (1968).

42. See Roy L. Brooks, Structures of Judicial Decision Making from Legal FORMALISM TO CRITICAL THEORY 169-84 (2d ed. 2005) [hereinafter BROOKS, STRUCTURES].

43. Id. at 183 .

44. See id. at 170 (stating that judicial positivism's normativity is the "idea that judicial decision making should be consistent not only with prior judicial rulings, but also with other governmental rulings ...").

45. $I d$.

46. See id. at 49-51 (discussing how all three favor private redistribution of wealth, thus disfavoring weaker economic groups). 
have far less than whites. ${ }^{47}$ Level 1 , then, freezes the status quo. It can even redistribute wealth upward, favoring the rich and powerful. ${ }^{48}$

Level 1 incorporates a minimalist predisposition (a preference for a weak national government ${ }^{49}$ ) that works against blacks. This fact was brought home by the Court's use of formalism in the latter years of the Rehnquist Court. "Between 1995 and 2000, the Court struck down all or part of twenty-five socially [progressive] federal statutes." case, the Court ruled that Congress "exceeded its powers under the Commerce Clause and Section 5 of the Fourteenth Amendment."

Originalism, especially Justice Scalia's brand of constitutional textualism, is a very dangerous judicial philosophy if one is black or any other minority. Justice Scalia's jurisprudence posits that the Constitution should be interpreted as it was written in 1791, the year in which the Bill of Rights was ratified. ${ }^{52}$ This is the so-called "Dead Constitution," in contradistinction to the "Living Constitution," which changes over time to keep up with society. ${ }^{53}$ Justice Scalia's Dead Constitution is predicated on the belief that society has not gotten better since 1791, and that freedoms have diminished over time. ${ }^{54}$

But for people of color, women, and homosexuals, society has gotten better. Slavery is gone; women have the right to self-determination, including a legal identity separate from that of their husbands; and homosexuals can, for the most part, "come out of the closet." Some even hold high public office. None of these "outsiders" wish to turn the clock back to 1791. For them, going back to the future is no way to go.

47. For example, the median net worth (bank accounts, stocks, bonds, real estate, and other assets) of white families is ten times more than that of black families (\$67,000 versus \$6166). Press Release, Nat'l Urban League, State of Black America Report 2006 Reveals Economic Status for African Americans is Getting Worse (Mar. 27, 2006), http://www.nul.org/PressReleases/ 2006/2006pr319.html (last visited Feb. 21, 2009). The racial gap is unbelievably larger within socioeconomic strata; for example, today "white middle-class families [had] on average 113 times more in financial assets than black middle-class families." Weekly Bull., JOURNAL OF BLACKS IN Higher EdUCATION, For Financing Higher Education, the Racial Wealth Gap Remains Huge (Mar. 1, 2007), http://www.jbhe.com/latest/index030107_p.html (last visited Feb. 21, 2009). See generally Melvin L. Oliver \& Thomas M. Shapiro, Black Wealth / White Wealth: A New PERSPECTIVE ON RACIAL INEQUALITY (2d ed. 2006) (analyzing racial inequality and the racial wealth gap in America).

48. See BROOKS, Structures, supra note 42 , at 49.

49. See id. at 39.

50. Id. at 59 .

51. Id. Perhaps the most controversial case involved gender rather than race. In United States v. Morrison, the Court struck down a remedial provision of the Violence Against Women Act. 529 U.S. 598, 602 (2000).

52. See BROOKS, STRUCTURES, supra note 42 , at 72.

53. See id. at 71-72.

54. See id. at 72 . 
Most tellingly, Justice Scalia's constitutional textualism not only embraces originalism (text frozen in time), but it also implicitly incorporates minimalism (the reduction of judicial discretion). ${ }^{55}$ Neither of these components would sustain the Court's decision in the most important civil rights case in history, Brown v. Board of Education. ${ }^{56}$ For example, Justice Scalia's originalism would reject reading the Fourteenth Amendment as a prohibition against segregation in public education. "[T]he Amendment's framers, the Thirty-ninth Congress, intended the Amendment to be read in harmony with" segregation-that is to say, "separate-but-equal." 57 "Indeed, Congress made no attempt to desegregate the public schools of Washington, D.C. These schools, as well as the public schools in the home districts of virtually every congressman who voted for the Amendment, were segregated both before and after the Amendment's passage." ${ }^{, 58}$

Like his originalism, Justice Scalia's minimalism would also reject the Court's reasoning in Brown. Rather than minimizing itself, the Supreme Court in Brown actually enlarged itself. It did so by overturning every state school segregation statute in the country, as well as seventy-five years of its own precedent. ${ }^{59}$

As an alternative to Level 1, the Court often proceeds at Level 2, which is commonly called judicial pragmatism. ${ }^{60}$ Judge Richard Posner opines that most of the great judges over the years have been judicial pragmatists. ${ }^{61}$ Level 2 can be defined as the quest for justice disciplined by what comes before the decision in the case (namely, rules and public policies) and by what comes after the decision (namely, the consequences the decision will have on a community). ${ }^{62}$ Unlike Level 1 , Level 2 is consequentialist and policy-oriented. ${ }^{63}$

The problem with this judicial philosophy from the perspective of blacks is that it does not go far enough in placing the judge in the path of unjust majorities. Level 2 is too respectful of the dominant community norms or expectations. ${ }^{64}$ A Level 2 judge is constrained by what Justice

55. See id. at 75 .

56. 347 U.S. 483 (1954).

57. BROOKS, StRUCtURES, supra note 42 , at 76 . For a discussion of the separate-but-equal doctrine, see supra text accompanying notes 31-33.

58. BROOKS, STRUCTURES, supra note 42, at 76.

59. See id. at 77 .

60. See id. at $172-74$.

61. See id. at 172

62. See id. at 183.

63. See id.

64. See id. at 174 
Oliver Wendell Holmes referred to as "[t]he felt necessities of the time." ${ }^{\circ 5}$ The judge cannot override strongly felt community expectations or values. Judge Posner, a master pragmatist, illustrates this point when he asserts that he "would not create a constitutional right of same-sex marriage because that would entail the imposition of 'a social policy that is deeply offensive to the vast majority of . . . [American] citizens." "66

In short, the problem with judicial pragmatism is that it is more majoritarian than egalitarian. Judicial pragmatism does not go far enough to protect minority interests. It does not permit a judge to impose norms on a community before the community is ready or willing to accept them. In other words, it does not allow "judicial policymaking." 67

The final level at which the Court traditionally operates, although not often, is Level 3. This is more commonly referred to as judicial nominalism. ${ }^{68}$ Level 3 can be described as the "search for justice disciplined only by the facts of the case." 99 The judge seeks justice in the case $s u b$ judice without regard to what comes before the decision or by what comes after the decision. ${ }^{70}$ Judicial nominalism's normativity, then, is the judge's commitment to the best results in particular cases. ${ }^{71}$ The judge is an activist and is not afraid to make law or policy, although he or she is reluctant to openly admit it.

One judge who was not afraid to admit his activism, albeit only after he had stepped down from the bench and was close to death, is the late Judge Skelly Wright. One of the most celebrated federal judges in the last half of the twentieth century, Judge Wright said in an interview shortly before his death:

'I guess I am an activist, but I want to do what's right. When I get a case, I look at it and the first thing I think of automatically is what's right, what should be done - and then you look at the law to see whether or not you can do it. That might invert the process of how you should arrive at a decision, of whether you should look at the law first, but [with me] it developed through making decisions, which involves resolving problems.... And I am less patient than other judges with law that won't permit what I conceive to be fair. Now, there's a

65. Oliver Wendell Holmes, The Common Law 5 (Mark DeWolfe Howe ed., 1963).

66. See BROOKS, STRUCTURES, supra note 42, at 190.

67. For a more detailed discussion of this concept of judicial policy-making, see $i d$. at 16-21.

68. See id. at 174-82.

69. Id. at 183 .

70. See id. at 180 (suggesting that the judge is essentially a roving moral commissioner whose moral viewpoint gives license to just about any type of judicial action).

71. See id. at 175 . 
legitimate criticism of that, because what's fair and just to $\mathrm{X}$ may not be fair and just to $\mathrm{Y}$-in perfect good faith on both sides. But if you don't take it to extremes, I think that it's good to come out with a fair and just result and then look for law to support it. ${ }^{, 72}$

Level 3 is problematic from a black perspective because it gives the judge too much discretion. Unbridled judicial power can act as an easy cover for conscious or unconscious bias against blacks. This is one of the lessons of critical theory.

Critical theory offers a general criticism of all three judicial models: Levels 1,2 , and $3 .^{73}$ It holds that each level operates upon the false assumption that our socio-legal order is fundamentally objective when it comes to matters of race, gender, or sexual orientation. Judge Posner's pragmatic views about same-sex marriage would seem to support the critical theorists observation, ${ }^{74}$ as do the race-related defects in each level of judicial reasoning just mentioned. ${ }^{75}$ The criticalist argument is that our socio-legal order and American culture in general are not culturally objective. ${ }^{76}$ American society, in a word, is anti-objective. ${ }^{77}$

For example, mainstream American society, critical theorists maintain, is not objective when it comes to race. ${ }^{78}$ American socio-legal arrangements are racially anti-objective, or "racist," because they give white Americans a cultural advantage. ${ }^{79}$ "Racism," as viewed by critical theorists, is less about racial antipathy, animus, or malevolent intent on the part of, say, individual Supreme Court Justices than about the cues the Court as an institution gives regarding what is culturally important and deserving of the Court's imprimatur. ${ }^{80}$ Hence, "racism" is not just about motivational bias, it is also about cognitive bias - the way in which we rationally order the external world, especially racial relations and identities. ${ }^{81}$ Cognitive bias is manifested in the actions of the republican official who, during the 2008 presidential election, distributed a caricature of Barack Obama surrounded by ribs, watermelon, and fried chicken. ${ }^{82}$ Although the official insisted she was not being racist and she

72. JACK BASS, UNLIKELY HEROES 116 (1981).

73. See BROOKS, STRUCTURES, supra note 42, at 187-91.

74. See supra text accompanying notes 65-66.

75. See supra text accompanying notes 40-74.

76. See BroOKS, Structures, supra note 42, at 193-225.

77. See id. at 193-227.

78. See id. at 211-25.

79. See id. at 212.

80. See id. at $193-227$.

81. See id. at 215-19.

82. See David Kelly, Newsletter's Obama Illustration Denounced, L.A. TIMES, Oct. 17, 2008, 
is not a white supremacist, the critical theorists would say intent has nothing to do with it. As viewed by critical theorists, "racism" incorporates all the negative ways in which whites actually see blacks.

\section{How to EFFECTUATE THE COURT'S ATONEMENT}

Given the identified deficiencies in the Court's extant judicial philosophies, the question becomes: how can the Court effectuate its atonement for slavery and Jim Crow? What does practical idealism suggest ${ }^{83}$ The issue does not concern the apology as much as the reparation. A judicial apology is a straightforward proposition, as the Court need only issue a simple statement of remorse. The reparation is more complex. In my view, it should entail the adoption of a judicial mindset that is self-consciously attuned to the life experiences of black Americans in today's society. The Court must vindicate black values whenever it has the discretion to do so. ${ }^{84}$ This may be the only way the Court can respond effectively to anti-objectivism. That is my idealism.

The practical side of practical idealism would place the Court's validation of black values within the traditional framework of judicial decision-making. Henry Hart and Albert Sacks, the principal pioneers of the legal process model in jurisprudence, have described the essential feature of the traditional judicial technique. ${ }^{85}$ According to Hart and Sacks, when a judge decides a case, she typically does so by "elaborating" the arrangements that form the basis of the decision in the case. $^{86}$ The judge, in other words, relates her reasoning back to existing arrangements - cultural norms as well as extant rules of law (statutory, constitutional, judge-made, and administrative). A judicial decision is unique in that, unlike other governmental officials, the judge, if he acts legitimately, identifies the established grounds on which the decision rests. ${ }^{87}$ Importantly, these grounds preexist the decision; they are not made up by the judge after the case is filed. ${ }^{88}$ Hence, we have the

at B1.

83. See supra text accompanying notes $10-11$.

84. For a detailed discussion of black values, see generally THE AFRICAN AMERICAN BOOK OF VALUES (Steven Barboza ed., 1998) (a compendium of essays, stories, and poetry discussing black values in detail).

85. See BROOKS, STRUCTURES, supra note 42, at 135-49.

86. Id. at 139 .

87. Id.

88. Id. 
famous principle: "reasoned elaboration from existing arrangements." 89 We certainly see this ex ante decision-making structure in Levels 1 and $2,{ }^{90}$ but less so in Level 3, ${ }^{91}$ which, in any event, is deemed by many to be an illegitimate form of judicial decision-making. Level 3 does not, however, have much of a presence in Anglo American law. ${ }^{92}$

Thus, within the traditional structure of Anglo American law we need to construct a kind of outsider jurisprudence that acts as the Court's reparation for slavery and Jim Crow. This can be done quite simply by the Court using reasoning based on well-established black values whenever possible. By giving deference to such external, extant arrangement, the Court not only avoids the type of ad hoc, unstable judicial decision-making for which Level 3 judges have been criticized, but she also mainstreams and, hence, legitimizes black values. What better way for the Court to atone for its participation in the atrocities of slavery and Jim Crow?

The governing principle, then, is reasoned elaboration from existing black values. As an institution, the Court can face its past moral transgressions visited upon blacks by vindicating the black perspective, which is too often subordinated under the Court's existing judicial philosophies. This reparatory standard of judicial review would help to counteract the white privilege, or anti-objectivism, that still has a definite presence in our legal system more than a half-century after Brown v. Board of Education.

I will give an example of the proposed judicial reparation, which can be called "outsider jurisprudence." My intention here is to be suggestive rather than comprehensive; in other words, move the discussion toward a more detailed consideration of outsider jurisprudence- $\mathrm{a}$ vision of the Court in post-atonement America. For purposes of illustration I shall use a non-racial legal problem, but one that, nonetheless, involves an outsider group. Taking the discussion out of the hyper-sensitive context of race may enable the reader to see the logic and reasonableness of outsider jurisprudence more clearly.

Plaintiff, a resident of California who has partial custody of her children, sues her former husband, a resident of New York, for child support. The case is filed in a California court. The trial court grants the defendant's motion to dismiss for lack of personal jurisdiction on grounds that the defendant has not stepped foot in California in the last

89. Id. at 138

90. See supra text accompanying notes $42-43,60-62$.

91. See supra text accompanying notes 68-72.

92. See Brooks, Structures, supra note 42 , at 174-82. 
sixteen or so years, and has no other "minimum contacts" with the forum state. $^{93}$ Upon appeal, the California appellate courts affirm the trial court's dismissal of the action. Subsequently, the case is appealed to the United States Supreme Court. There, the justices uphold the California Supreme Court's judgment on grounds that the defendant lacks minimum contacts with the state. Under the minimum contacts doctrine, the defendant must have sufficient contact with the forum state as a precondition for the state to render a valid judgment against the defendant. $^{94}$ The Court construes minimum contacts to mean commercial ties between the defendant and the forum state. ${ }^{95}$ Accordingly, because " $[\mathrm{t}]$ he cause of action herein asserted arises, not from the defendant's commercial transactions in interstate commerce, but rather from his personal, domestic relations," 96 the California Supreme Court's judgment is affirmed. ${ }^{97}$

The Court's judgment and reasoning subordinates women by making it difficult, if not impossible, for them to sue for child support against a nonresident ex-husband. Had the Court used outsider jurisprudence, both its judgment and reasoning would have been more accommodating. The female plaintiff would have been given her day in court and, in the process, the Court would have validated well-established outsider (in this case gender) values relevant to the facts of the case. Specifically, the Court's interpretation of the minimum contacts doctrine would reach back to the relevant gender value of care and connection, in this case, the nurturing of children. Psychological studies show that "women experience themselves through connections and relationships to others while men see themselves as separately identified individuals.... [W]omen express... vulnerability instead of strength, and responsiveness instead of independence." 98

93. See, e.g., Burger King v. Rudzewicz, 471 U.S. 462 (1985) (stating a forum may assert jurisdiction over a nonresident if the individual has purposefully directed actions toward residents of that state and if the exercise of jurisdiction would not offend fair play and substantial justice); World-Wide Volkswagen Corp. v. Woodson, 444 U.S. 286 (1980) (holding there was no personal jurisdiction over individuals who had not purposefully directed their actions toward the forum state); Int'l Shoe Co. v. Washington, 326 U.S. 310 (1945) (holding that in order for an individual to be subjected to personal jurisdiction he must maintain minimum contacts such that the suit would not offend traditional notions of fair play and substantial justice).

94. See Int'l Shoe, 326 U.S. at 316.

95. Id. at $318-19$.

96. Kulko v. Superior Court, 436 U.S. 84, 97 (1978).

97. Id. at 101 .

98. Carrie Menkel-Meadow, Portia in a Different Voice: Speculations on a Women's Lawyering Process, 1 BerKeley WOMEN's L.J. 39, 43 (1985). Psychologists believe "these differences are the result of a childrearing system which is based on mothering, so that growing up is a process of identification and connection for a girl and separation and individuation for a boy." Id. 
Thus, the love of children, the special historical relationship that women have with children, would inform the way in which the Court defines minimum contacts. This important legal doctrine would include personal ties as well as commercial ties. The California Supreme Court's judgment would be reversed because the defendant's relationship with his children would be deemed sufficient to establish minimum contacts between the defendant and the forum state. A child is more than a minimum contact; he is a meaningful contact.

The point I wish to make is this: outsider jurisprudence is possible. Judges can render decisions that elaborate on existing outsider arrangements. Further, outsider values are not necessarily unreasonable. They do make sense-legally, culturally, and morally. The Court need only discover and apply these values. In doing so, the Court could embrace outsider jurisprudence as its reparatory response to the atrocities of slavery and Jim Crow for which it bears no dearth of moral culpability.

\section{CONCLUSION}

My argument for judicial atonement can be summarized in the following syllogism: when a government or a government institution "commits an atrocity against an innocent people, it has, at the very least, a moral obligation to apologize and to make that apology believable by doing something tangible called a "reparation." 99 The United States Supreme Court committed atrocities against an innocent people by upholding the legality of racial oppression in the forms of slavery and Jim Crow. Ergo, the Court "should, in fact, atone- that is, both apologize and provide reparations"-for slavery and Jim Crow. ${ }^{100}$ Outsider jurisprudence is one way the Court can effectuate such atonement.

99. BROOKS, ATONEMENT AND FORGIVENESS, supra note 1, at ix.

100. Id. 